\title{
Variation on the Fluxes of Nutrients in an Urban Lagoon by Seasonal Effects and Human Activities
}

\author{
Alejandro Ruiz-Marín*, Yunuen Canedo-López, José del Carmen Zavala-Loría, Reyes R, García-Sarracino, Francisco Anguebes- \\ Franseschi and Atl Víctor Córdova Quiroz
}

Universidad Autónoma de Ciudad del Carmen Ciudad del Carmen, Campeche, México

\begin{abstract}
This document to examine the changes occurred in the flux of nutrients and NEM during dry season and rainy + north wind season in the Caleta system located within the Términos lagoon natural reserve which presents negative impacts caused by discharges of urban wastewater. Salinity, dissolved oxygen, chlorophyll a, nitrogen and phosphorus were monitored during nine months considering the dry, rainy and north wind season. Storms caused sediment disturbances which increased the amount of nutrients into the Caleta system as well as the phytoplankton production $\left(25 \mathrm{mg} \mathrm{m}^{-3}\right)$. The system shows longer times of water renovation during the summer $(21 \mathrm{~d})$ unlike $(6$ d) during the rainy + north wind season. On one hand, the $\triangle$ DIP values during dry season $\left(0.0049 \mu \mathrm{mol} \mathrm{m}^{-2} \mathrm{~d}^{-1}\right)$ establishes the system as producer and exporter of DIP into the ocean; on the other hand, the $\triangle$ DIP during rainy + north wind seasons $\left(-0.0039 \mu \mathrm{mol} \mathrm{m}^{-2} \mathrm{~d}^{-1}\right)$ suggests the importation of phosphorus from the ocean. Likewise, the system exports DIN $\left(0.0031 \mu \mathrm{mol} \mathrm{m}^{-2} \mathrm{~d}^{-1}\right)$ during the summer and imports DIN $\left(-0.0048 \mu \mathrm{mol} \mathrm{m}^{-2} \mathrm{~d}^{-1}\right)$, during the rainy + north wind seasons. The negative values of fixation-denitrification and NEM during the summer turn the system into a nitrogen sink. Seasonal changes were present in the system, dominated by heterotrophic NEM during summer with higher nitrogen fixation; while an autotrophic NEM dominated during winter.
\end{abstract}

Keywords: Términos Lagoon; Nutrients balance; Nitrogen; Net metabolism

\section{Introduction}

The coastal lagoon and the estuaries are zones of mixture exchange of epicontinental and marine water masses passing by natural inlets, artificial streams or tides that, along with the morphology and dynamic of the currents favor different environments that are considered as an adequate habitat for a significant number of important species at a commercial level [1]. The exchange and balance of energy and materials in the different kinds of coastal water bodies are considered as spatial and temporal variables that depend on continental and marine contributions, local morphology and bathymetry, and even on regular and eventual climatic factors (north wind and hurricanes) that characterize the region. Heterogeneous and controversial results are obtained as a result of the high number of factors involved in such exchange [2,3]. Some studies have reported that events such as tropical storms and hurricanes can have a direct impact on salinity and increase the concentration of nutrients, phytoplankton and organic matter as well as to cause hypoxia $\left(\mathrm{DO}<2 \mathrm{mg} \mathrm{l}^{-1}\right) /$ anoxia $\left(\mathrm{DO}=0 \mathrm{mg} \mathrm{l}^{-1}\right)$ in estuaries $[4,5]$.

Pluvial runoffs typically provide nitrogen to water bodies. Some studies suggest that one month after a storm or hurricane the chlorophyll concentration can reach values up to $20 \mu \mathrm{g}^{-1}$ [5]. When phytoplankton dies it sediments favoring mineralization in the water column. The nitrogen and phosphorous fluxes increase, as well as the nitrification rates. After a storm, Smith and Caffrey [6] reported increases in the nitrification rates in shallow areas of Escambia Bay, Florida. Shallow areas are susceptible to disturbances and sediment resuspension.

Primary production, respiration and net ecosystem metabolism (NEM) vary through ecosystems, going from highly productive to oligotrophic. NEM is a useful indicator of ecosystem level trophic conditions. If NEM is positive, the system is autotrophic and suggests that internal production of organic matter dominates, while if NEM is negative the system is heterotrophic and relies on external sources of organic [7]. Since primary production and respiration vary in aquatic ecosystems, is useful to determine NEM [8] in ecosystem principally when are affected by the human activities.

The study of coastal lagoons and estuaries requires the analysis of the interaction between land and marine zones as well as the factors that alter their original characteristics caused by the growing anthropogenic activity that cause local and regional changes having an impact in the primary production and fishing $[9,10]$. The major contribution of water and nutrients can come of the discharges of wastewater, being the nitrogen one of the factors for the process of eutrophication. When the organic wastes volume increases in the water column, the removal capacity decreases until the oxygen runs out. The combination of the chemical and biological processes where the organic charge is mineralized is known as self-depuration process.

The constant incorporation of organic compounds from fertilizers, wastes, urban development and aquaculture have significantly raise the nitrogen rates in estuaries [11], increasing the presence of algae and chronic effects over several organisms and diminishing the levels of oxygen in the water which could leads to eliminate nitrification [12]. Studies have reported that the salinity, temperature, chlorophyll concentrations, solar irradiance, nutrient loading, organic loading and residence time are important factors to control metabolic rates; however, the nutrients and organic loading have been hypothesized

*Corresponding author: Alejandro Ruiz-Marín, Universidad Autónoma de Ciudad del Carmen. Calle 56 \#4 Av Concordia Ciudad del Carmen, Campeche, CP 24180 México, Tel: 529383811018; E-mail: aruiz@pampano.unacar.mx

Received March 11, 2014; Accepted April 24, 2014; Published April 30, 2014

Citation: Marín AR, López YC, Loría JCZ, Reyes R, Sarracino G, et al. (2014) Variation on the Fluxes of Nutrients in an Urban Lagoon by Seasonal Effects and Human Activities. Hydrol Current Res 5: 170. doi:10.4172/2157-7587.1000170

Copyright: ( 2014 Marín AR, et al. This is an open-access article distributed under the terms of the Creative Commons Attribution License, which permits unrestricted use, distribution, and reproduction in any medium, provided the original author and source are credited. 
Citation: Marín AR, López YC, Loría JCZ, Reyes R, Sarracino G, et al. (2014) Variation on the Fluxes of Nutrients in an Urban Lagoon by Seasonal Effects and Human Activities. Hydrol Current Res 5: 170. doi:10.4172/2157-7587.1000170

Page 2 of 8

to explain variations in rates of net ecosystem metabolism in different estuaries [7].

The objective of this study is to estimate the nutrient fluxes and net metabolism during dry, rains and north wind seasons within the area of the Caleta lagoon located in Isla of Carmen, Mexico. This lagoon has an estimated longitude of $7 \mathrm{~km}$ and an approximate depth of $1.5 \mathrm{~m}$; the presence of mangroves is scarce and the lagoon connects with Términos lagoon and the Gulf of Mexico at the West. The water column has been affected by urban wastewater discharges and high concentrations of organic matter and nutrients $(\mathrm{N}$ and $\mathrm{P})$.

\section{Materials and Methods}

\section{Study area}

Isla of Carmen is a sand barrier located at the southern extreme of the Gulf of Mexico between $91^{\circ} 15^{\prime}$ and $92^{\circ} 00^{\prime}$ west and $18^{\circ} 15^{\prime}$ and $19^{\circ} 00^{\prime}$ north. It measures approximately $37.5 \mathrm{~km}$ long and $3 \mathrm{~km}$ wide, it is separated from the continent by two inlets called: Channel West and Channel East (Figure 1). Términos lagoon is located at the southern extreme of Isla of Carmen, the lagoon measures $2,500 \mathrm{~km}^{2}$ approximately; its average depth is $3.5 \mathrm{~m}$ [13].

The study area, Caleta lagoon is located at the western extreme of Isla of Carmen, it measures $7 \mathrm{~km}$ long, and average depth of $1.5 \mathrm{~m}$. The system has an area of $140000 \mathrm{~m}^{2}$ and a volume of $210000 \mathrm{~m}^{3}$, that communicates at the west with Términos lagoon and the ocean (Figure 1). Oil companies, fisheries and urban development's surround this area, and discharge $613,260 \mathrm{~m}^{3}$ of wastewater every year, affecting negatively the ecosystem. The communication that exists between Caleta lagoon, Términos lagoon and the ocean put at risk the recreational character of the main beaches in Isla of Carmen. The analysis of wastewater reported by System of Water and Sewer of Carmen (SMAPAC) in 2007 showed that the three most important treatment plants in the city present high values of nitrogen (99.13 $\mathrm{mg} \mathrm{l}^{-1}$ ), phosphorus (19.64 mg $\left.\mathrm{l}^{-1}\right)$, and biochemical oxygen demand $\left(212 \mathrm{mg} \mathrm{l}^{-1}\right)$ (Table 1$)$. On the other hand, urban wastewater effluents clandestine are discharged to the Caleta which have not been quantified in volume and concentration of contaminants.

The coastal zone have diurnal tides with a mean range of $0.4 \mathrm{~m}$ that can go from -0.5 to $0.7 \mathrm{~m}$.; the tides force the lagoon through Channel west and Channel East and produce a mixing of water masses within Términos lagoon. The weather is humid and tropical; the average annual precipitation is measured to be $1100-2000 \mathrm{~mm}$. The Términos lagoon region present three distinct seasons: north wind season (from November to February), rains season (from June to October), and dry season (from March to May). The average temperature oscillates between $17^{\circ} \mathrm{C}$ and $35^{\circ} \mathrm{C}$. Mangroves and plants in flood areas mainly form the dominant habitat; that have disappeared mainly as a result of indiscriminate deforestation and the use of soil to build urban development's [13].

Salinity, dissolved oxygen, chlorophyll $\boldsymbol{a}$, total nitrogen and total phosphorous were monitored within the Caleta lagoon at $2.0 \mathrm{~km}$ and $5.0 \mathrm{~km}$. The temperature, salinity, $\mathrm{pH}$ and dissolved oxygen were

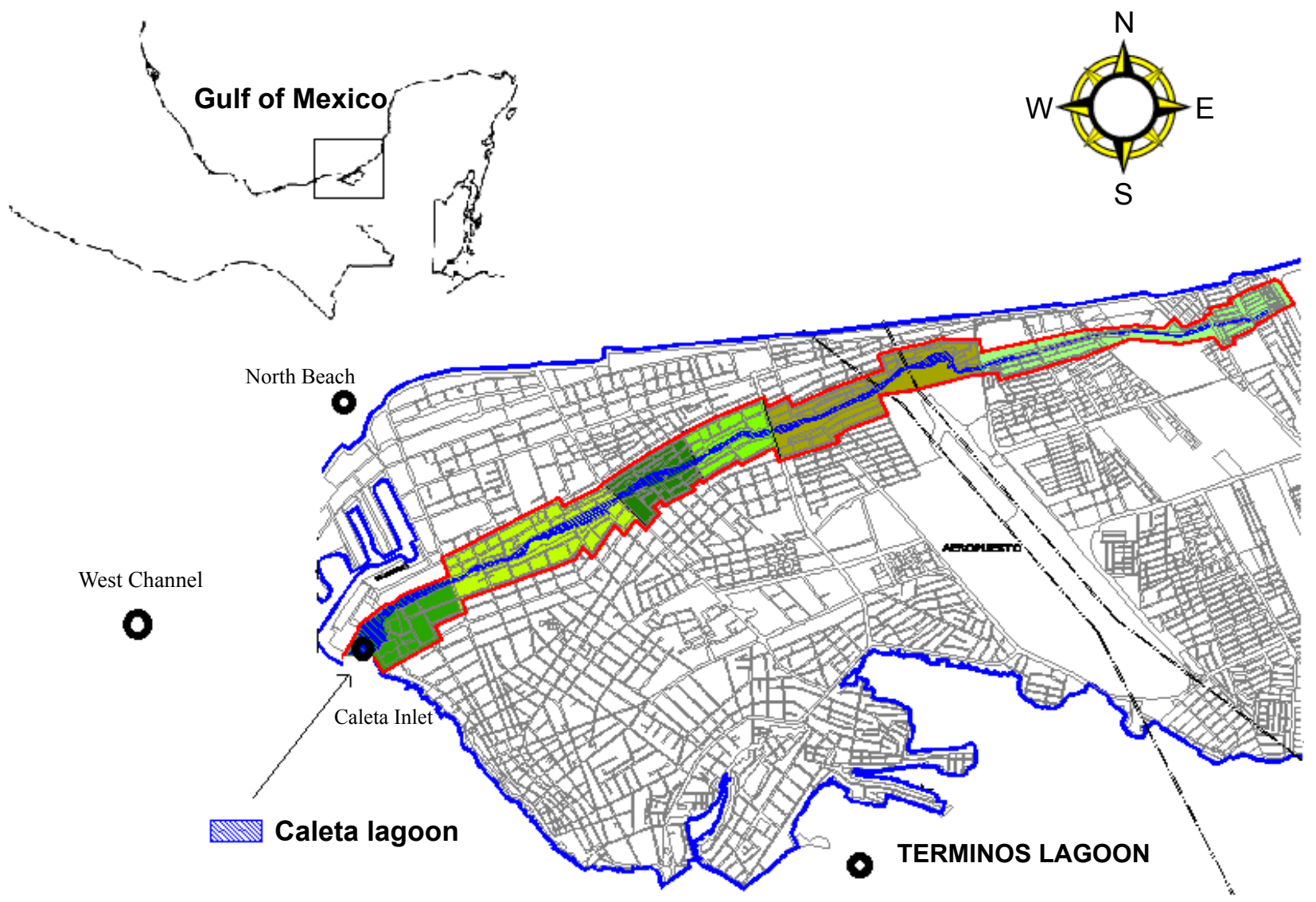

Figure 1: Location of the study area (Caleta lagoon) at Carmen City, Campeche. 


\begin{tabular}{|c|c|c|c|c|}
\hline \multirow[t]{2}{*}{ Parameter } & \multirow[t]{2}{*}{ Units } & \multicolumn{3}{|c|}{$\begin{array}{l}\text { Wastewater Treatment Plants } \\
\text { effluents }\end{array}$} \\
\hline & & WTP 1 & WTP 2 & WTP 3 \\
\hline Temperature & ${ }^{\circ} \mathrm{C}$ & 26.3 & 27 & 27 \\
\hline $\mathrm{pH}$ & --- & 7.96 & 7.47 & 7.10 \\
\hline Total Nitrogen & $\mathrm{mg} \mathrm{l}^{-1}$ & 99.13 & 18.64 & 3.10 \\
\hline Total Phosphorus & $\mathrm{mg} \mathrm{l}^{-1}$ & 19.64 & 3.75 & 4.22 \\
\hline Fat and oil & $\mathrm{mg} \mathrm{l}^{-1}$ & 20.26 & 8.03 & 10.75 \\
\hline $\begin{array}{l}\text { Biochemical oxygen } \\
\text { demand (BOD) }\end{array}$ & $\mathrm{mg} \mathrm{l}^{-1}$ & 212 & 28 & 43.0 \\
\hline Suspended solids & $\mathrm{mg} \mathrm{l}^{-1}$ & 117 & 27 & 40 \\
\hline Faecal coliform & MPN $100 \mathrm{ml}^{-1}$ & 9 & $<3$ & $<3$ \\
\hline
\end{tabular}

Table 1: Characterization of Wastewater Treatment Plants (WTP) effluents discharged into Caleta lagoonal system (SMAPAC, 2007).

measured in situ with a Sonda Hydrolab Data 4 placed on the surface of the water in every station; at the same time, other samples of water from the surface were collected with a Van-Dorn bottle. The samples were preserved at $4^{\circ} \mathrm{C}$ and the same day were sent to the Environmental Science laboratory at the Autonomous University of Carmen to determine the amount of phosphorous $\left(\mathrm{P}-\mathrm{PO}_{4}\right)$, total nitrogen $(\mathrm{TN})$ through the NT Kjeldahl method, the BOD was determined through the five-days incubation method [14], and the chlorophyll a (Chl a) was determined according to the techniques described on the Standard method [14], the analysis were carried out in a 24 hours period.

Additionally, samples of water were collected in sites near to the Caleta lagoon: Términos lagoon, Caleta inlet, channel west and north beach, to determinate the impact of the urban wastewater effluents. The samples were collected during the three distinctive seasons (north winds season, dry season and rainy season), more specifically during January, February, March, May, June, July, October, November and December. The salinity rates, dissolved oxygen and chlorophyll $\boldsymbol{a}$ obtained during the north wind and rainy season were an averaged. The estimation of conservative materials (water and salt), non-conservative materials (nutrients), and NEM was based on the method proposed by Hernández-Ayón et al. [15].

Salt and water budget: To obtain the salt and water budget in Caleta lagoon was according to the equation $\left(\mathrm{dV}_{\text {system }} / \mathrm{dt}=0=\mathrm{V}_{\mathrm{Q}}+\mathrm{V}_{\mathrm{P}}\right.$ $\left.+V_{E}+V_{G}+V_{O}+V_{R}\right)$, so that the residual volume $\left(V_{R}\right)$ compensated the net gains or losses of fresh water, according to the equation:

$$
V_{R}=-\left(V_{Q}+V_{P}+V_{E}+V_{G}+V_{O}\right)
$$

Where the freshwater inputs considered were: $V_{Q}$ as wastewater discharged; $\mathrm{V}_{\mathrm{G}}$ : Groundwater; $\mathrm{V}_{\mathrm{P}}$ : Precipitation; $\mathrm{V}_{\mathrm{E}}$ : Evaporation and $\mathrm{V}_{\mathrm{O}}$ : Outfalls.

During this study, the urban wastewater input $\left(\mathrm{V}_{\mathrm{Q}}\right)$ in the Caleta system, was considered to be the same during the rain, dry and north winds season. The values estimated of the diverse contributions of water that input to the system during the climatic seasons is showed in the Table 2. It was considered that dissolved salt was eliminated or added to the Systems via mixing $\left(\mathrm{V}_{\mathrm{X}}\right)$ and advection $\left(\mathrm{V}_{\mathrm{R}}\right)$ as described in equation [16].

$$
V_{X}=\frac{\left(-V_{R} S_{R}\right)}{S_{\text {Ocn }}-S_{\text {Syst }}}
$$

Where $\mathrm{S}_{\mathrm{Ocn}}$ is the salinity in the ocean; $\mathrm{S}_{\text {Syst }}$ the salinity in the system and $S_{R}$ is the average salinity between Caleta lagoon and the sea. Based on this information, the residence time $(\tau)$ was estimated with the equation:

$$
\tau=\frac{V_{S y s t}}{V_{x}+\left|V_{R}\right|}
$$

Nutrients budget: In order to estimate the non-conservative flux of nutrients, an equation similar to the salt and water equation was used. The only exception is that the non-conservative term $(\Delta \mathrm{Y})$ was included which indicates whether the system is a net source sink of these materials: $+\Delta \mathrm{Y}$

$\mathrm{d}(\mathrm{VY}) / \mathrm{dt}=\mathrm{V}_{\mathrm{Q}} \mathrm{Y}_{\mathrm{Q}}+\mathrm{V}_{\mathrm{P}} \mathrm{Y}_{\mathrm{P}}+\mathrm{V}_{\mathrm{G}} \mathrm{Y}_{\mathrm{G}}+\mathrm{V}_{\mathrm{E}} \mathrm{Y}_{\mathrm{E}}+\mathrm{V}_{\mathrm{R}} \mathrm{Y}_{\mathrm{R}}+\mathrm{V}_{\mathrm{X}}\left(\mathrm{Y}_{\text {Ocn }}-\mathrm{Y}_{\text {Syst }}\right)$

The equation that represents the phosphorus flux is:

$\Delta \mathrm{DIP}=\mathrm{V}_{\mathrm{R}} \mathrm{DIP}_{\mathrm{R}}-\mathrm{V}_{\mathrm{X}}\left(\mathrm{DIP}_{\text {Ocn }}-\mathrm{DIP}_{\text {Syst }}\right)$

Where $\mathrm{DIP}_{\text {Ocn }}$ and $\mathrm{DIP}_{\text {Syst }}$ represent molar concentrations of inorganic phosphorous in the adjacent sea and in la Caleta lagoon; $\mathrm{DIP}_{\mathrm{R}}$ is the concentration associated to residual flux (average between $\mathrm{DIP}_{\mathrm{Ocn}}$ and DIP $\mathrm{Syst}_{\mathrm{st}}$ ). The same equation was used to estimate $\triangle \mathrm{DIN}$.

NEM and (Nfix-Denit) estimation: The NEM (productionrespiration) and the balance between nitrogen fixation and denitrification (nfix-denit) were estimated stechiometrically based on dissolved inorganic phosphorus (DIP) and dissolved inorganic nitrogen (DIN), assuming a Redfield relation for the carbon: phosphorus (C:P) ratio of 106:1, and for nitrogen : phosphorus $(\mathrm{N}: \mathrm{P})$ ratio of $16: 1$, as indicated below:

$$
\begin{aligned}
& \mathrm{NEM}=\Delta \mathrm{DIP} \times 106 \\
& (n f i x-\text { denit })=\Delta \mathrm{DIN}_{\text {obs }}-\Delta \mathrm{DIN}_{\text {exp }} \\
& =\Delta \mathrm{DIN}_{\text {obs }}-\Delta \mathrm{DIP} \times 16
\end{aligned}
$$

Where, $\Delta \mathrm{DIN}_{\mathrm{obs}}$ is the non-conservative flux of DIN, $\Delta \mathrm{DIN}_{\text {exp }}$ is the expected non-conservative flux of DIN calculated according to the Redfield ratio ( $=16 \times \Delta \mathrm{DIP})$, and $\Delta \mathrm{DIP}$ is the non-conservative flux of DIP.

Estimation of biochemical oxygen demand (BOD): To estimate BOD eliminated from urban wastewater discharged into Caleta system, values of $200 \mathrm{mg} \mathrm{l}^{-1}$ were considered for the three seasons (dry, rains and north winds). The equation below was used [17].

$$
\frac{S}{S o}=\frac{1}{1+k\left(\frac{V}{Q}\right)}
$$

Where

\section{$\mathrm{S}=\mathrm{BOD}$ of the effluent $\left(\mathrm{mg} \mathrm{l}^{-1}\right)$}

$\mathrm{S}_{\mathrm{o}}=\mathrm{BOD}$ of the affluent $\left(\mathrm{mg} \mathrm{l}^{-1}\right)$

$k=$ Constant of elimination

\begin{tabular}{|c|c|c|}
\hline Freshwater inputs & $\begin{array}{c}\text { Rains + winds north season } \\
\left(\mathbf{m}^{3} \text { annual) }\right.\end{array}$ & $\begin{array}{c}\text { Dry season } \\
\left(\mathbf{m}^{3} \text { annual }\right)\end{array}$ \\
\hline Wastewater discharged $\left(\mathrm{V}_{\mathrm{Q}}\right)$ & 613260.00 & 613260.00 \\
\hline Groundwater $\left(\mathrm{V}_{\mathrm{G}}\right)$ & 0 & 0 \\
\hline Precipitation $\left(\mathrm{V}_{\mathrm{P}}\right)$ & 280000.00 & 128800.00 \\
\hline Evaporation $\left(\mathrm{V}_{\mathrm{E}}\right)$ & 196000.00 & 235200.00 \\
\hline Outfalls $\left(\mathrm{V}_{\mathrm{O}}\right)$ & 0 & 0 \\
\hline
\end{tabular}

Table 2: Water contributions in the Caleta system. 


\section{$\mathrm{V}=$ Volume of the system \\ $\mathrm{Q}=$ Exchange flow $\left(\mathrm{m}^{3} \mathrm{~d}^{-1}\right)$}

The relation V/Q represents the residence time $(\tau)$, which was calculated from the salt and water budget for every season. The elimination constant $(k)$ was adjusted according to the temperature used the equation

$$
\frac{K_{T}}{K_{20^{\circ} \mathrm{C}}}=\theta^{T-20}
$$

Where $\mathrm{K}$ at $20^{\circ} \mathrm{C}$ was 2.5 and $\theta$ was $1.6 . \mathrm{K}_{\mathrm{T}}$ was obtained from the average temperature in the water column during the dry season $\left(30^{\circ}\right.$ $\mathrm{C})$, and rains+north wind season $\left(26^{\circ} \mathrm{C}\right)$.

\section{Results}

The salinity in the sampling stations (Términos lagoon, Channel west, Caleta inlet and North beach) showed significant differences (ANOVA, $P=0.002$ ) between the climatic seasons. At the beginning of the dry season, the salinity increased from 12 to 32; however, the higher values were reported during the rains season (June) increasing from 34 to 36 , finally they decreased during the north wind season (December, January and February) from 18 to 20 (Figure 2). The average salinity in the Caleta system was 28 during the dry season and 8 during the rains and north wind season (Table 3).

In contrast, $\mathrm{pH}(8.0-9.1)$ did not show significant variations (ANOVA, $P=0.645$ ) between the seasons and the sampling stations.
The minimum surface water temperature during the north wind season was $27^{\circ} \mathrm{C}$ and at the beginning of the dry season was $28^{\circ} \mathrm{C}$. The months of June and July (rains season) presented the highest temperature of $32^{\circ} \mathrm{C}$ (these data are not shown in this study).

The oxygen concentration showed significant differences $(\mathrm{P}=0.0012)$ between the climatic seasons. Intervals of $8-9 \mathrm{mg} \mathrm{l}^{-1}$ were obtained during the dry season in every sampling station located in the adjacent sea. The oxygen levels decreased during the rains and north wind season $\left(6 \mathrm{mg} \mathrm{l}^{-1}\right)$ (Figure 3). As for the Caleta system, the lowest average concentration of oxygen $\left(2.6 \mathrm{mg} \mathrm{l}^{-1}\right)$ was obtained at the upper section of the system $(5 \mathrm{~km})$ during the dry and rains+north wind season; while the average concentration of oxygen was similar to the observed in the adjacent sea in the section to $2 \mathrm{~km}$ of the stream and at the Caleta inlet.

The average concentrations of DIN and DIP during the dry season were higher in Caleta system $\left(0.140\right.$ and $\left.0.685 \mathrm{mmol} \mathrm{l}^{-1}\right)$, with respect to the adjacent sea showed concentrations of 0.035 and $0.501 \mathrm{mmol}$ $\mathrm{l}^{-1}$. During the rain and north wind season, the DIN and DIP contents slightly increased at the adjacent sea $\left(0.058\right.$ and $\left.0.371 \mathrm{mmol} \mathrm{l}^{-1}\right)$ while in the Caleta system they were 0.030 and $0.208 \mathrm{mmol} \mathrm{l}^{-1}$. It is worth mentioning that during the dry season the nitrogen concentration was higher in both, the Caleta system and the adjacent sea, while the content of phosphorus was higher only in the Caleta system (Table 3).

The content of chlorophyll $\boldsymbol{a}$ varied considerably during the months of study. The highest concentrations of chlorophyll $\boldsymbol{a}$ were obtained during the rains and north wind season unlike the dry season

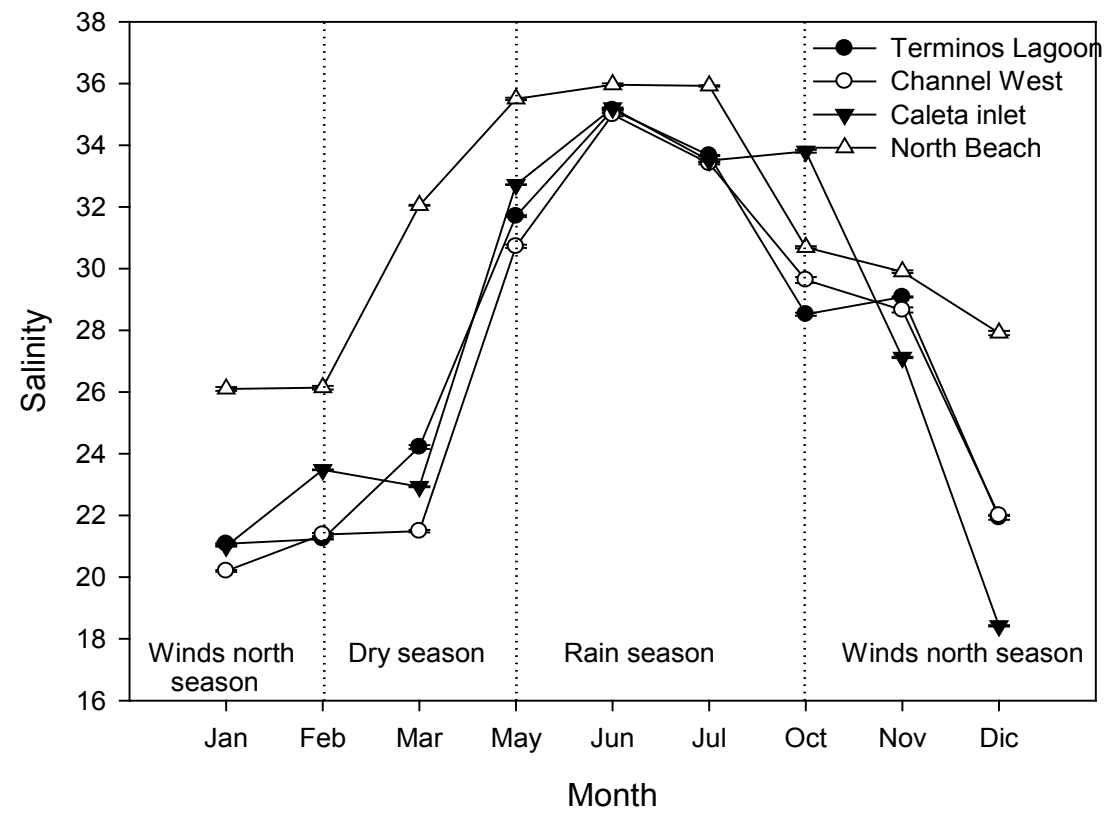

Figure 2: Salinity variation during the three climatic seasons and sampling months.

\begin{tabular}{|c|c|c|c|}
\hline Season & & Salinity & DIP (mmol I-1) \\
\hline Dry & Ocean & 35 & $0.035^{\mathrm{a}}$ \\
\hline & Caleta System & $0.501^{\mathrm{a}}$ & $0.140^{\mathrm{b}}$ \\
\hline Rains + Winds north & Ocean & 28 & $0.685^{\mathrm{a}}$ \\
\hline & Caleta System & 24 & $0.058^{\mathrm{b}}$ \\
\hline
\end{tabular}

* Different letters showed significant differences (Tukey, $\alpha=0.05$ )

Table 3: Average concentration of salinity and nutrients in Caleta system and the adjacent sea. 


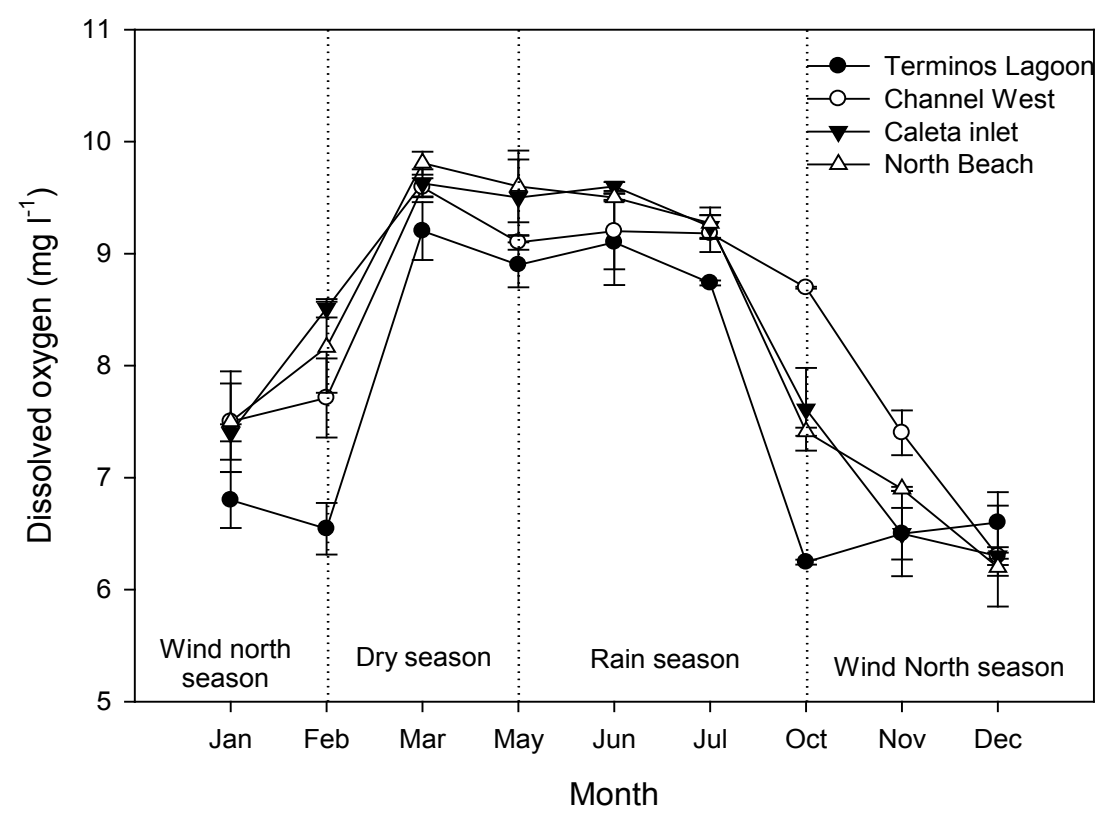

Figure 3: Average concentration of oxygen during the months of study in Caleta system as well as in the adjacent sea.

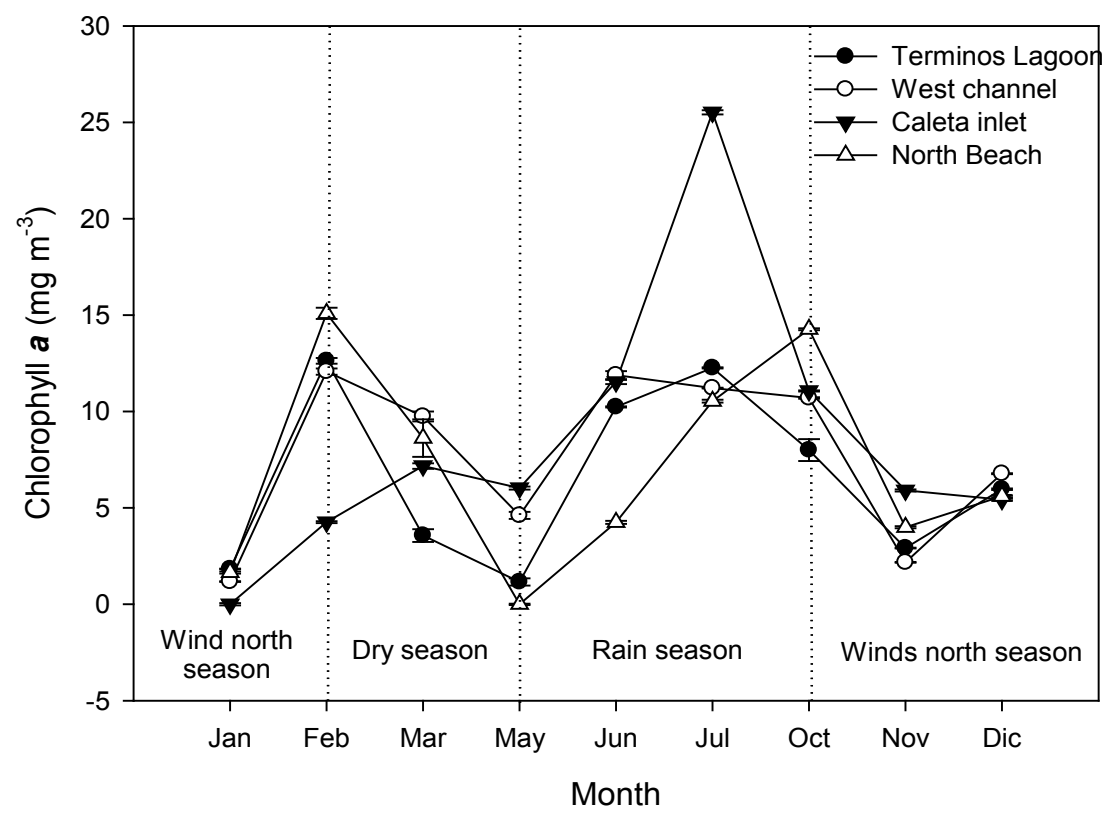

Figure 4: Average concentration of chlorophyll $\mathbf{a}\left(\mathrm{mg} \mathrm{m}^{-3}\right)$ during the months of study in Caleta system and the adjacent sea.

were the lowest concentrations obtained. In the course of the year, it was possible to perceive two important increments of chlorophyll $\boldsymbol{a}$, however the month february is considered as a month of transition between the north wind season and the dry season, while July and October are considered as months of storms. Thus, after storm events the contents of chlorophyll $\boldsymbol{a}$ tend to increase, while they decrease during the dry season. The Caleta inlet station presented a high content of chlorophyll $\boldsymbol{a}\left(25 \mathrm{mg} \mathrm{m}^{-3}\right)$ during the rains and north wind season, in contrast to the internal zone of Caleta system $\left(13.0 \mathrm{mg} \mathrm{m}^{-3}\right)$ and the adjacent sea of $10 \mathrm{mg} \mathrm{m}^{-3}$ (Figure 4).
The salt and water budget indicated residence times $(\tau)$ of 21 and 6 days during the dry and rain + north wind season, respectively (Figure 5). The positive values of $\Delta \mathrm{DIP}\left(0.0049 \mu \mathrm{mol} \mathrm{m}^{-2} \mathrm{~d}^{-1}\right)$ during the dry season at the Caleta system make of it a DIP producer and probably an exporter of this nutrient into the ocean; while during the rains season, the negative value of $\Delta \mathrm{DIP}\left(-0.00077 \mu \mathrm{mol} \mathrm{m}^{-2} \mathrm{~d}^{-1}\right)$ suggests that the system may import phosphorous from the ocean. As a consequence, NEM values are negative during the dry season, while they are positive during the rains season; this indicates changes through the year: system heterotrophic in the dry season and system autotrophic in the rains+north wind season (Table 4). The $\Delta \mathrm{DIN}$ values presented 


\section{DRY SEASON}

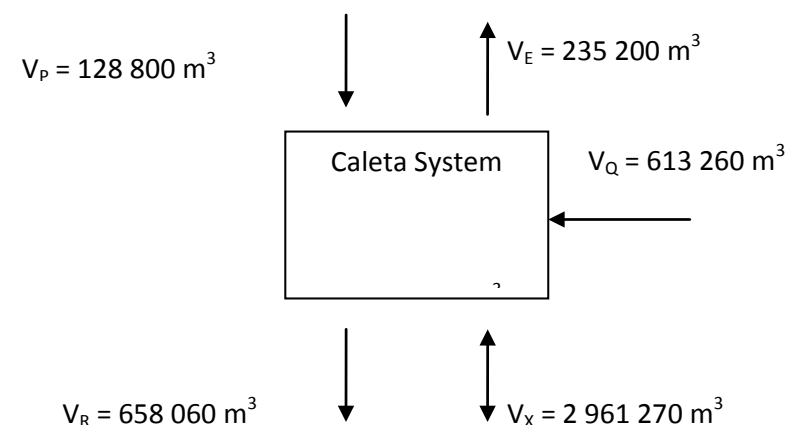

RAINS AND WINDS NORTH

SEASON

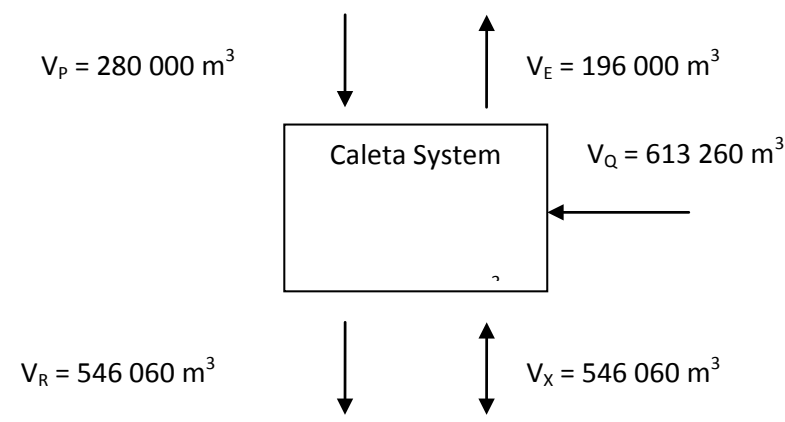

Figure 5: Salt and water budget during the dry and the rains+north wind season in Caleta system.

\begin{tabular}{|c|c|c|c|c|}
\hline Season & $\Delta$ DIP & \multicolumn{4}{|c|}{$\boldsymbol{\Delta D I N}$} & nfix-denit & NEM \\
\hline & \multicolumn{4}{|c|}{$\left(\boldsymbol{\mu m o l} \mathbf{~ m}^{-2} \mathbf{d}^{-1}\right)$} \\
\hline Dry & 0.0049 & 0.0031 & -0.075 & -0.522 \\
\hline Rains + Winds north & -0.00077 & -0.0048 & 0.0074 & 0.081 \\
\hline
\end{tabular}

Table 4: Flux of non-conservative nutrients and stechiometrically calculations based on Caleta system.

a similar trend. The system exports DIN to the ocean during the dry season and imports it during the rains+north wind season (Table 4). The negative indicator for nfix-denit and NEM during the dry season is associated to the system as nitrogen sink (Table 4).

The analysis realized to determine the elimination of the BOD showed that from an initial concentration of $200 \mathrm{mg} \mathrm{l}^{-1}$, which is contained in the urban wastewater, showed that the organic matter is oxidizes until it reaches a minimum concentration of $8.56 \mathrm{mg} \mathrm{l}^{-1}$ (dry season) and $44.05 \mathrm{mg} \mathrm{l}^{-1}$ (rain season) at the Caleta inlet and along 7 $\mathrm{km}$. This represents $96 \%$ and $78 \%$ of BOD eliminated during the dry season and the rain + north wind season, respectively.

\section{Discussion}

The salinity varied considerably between the climatic seasons. There was a gradually increased during the dry season and reached maximum values at the beginning of the rains season, finally the levels decreased during the north wind season. All this, suggests that the dilution processes contribute to the salinity decrease during the north wind season. Salinity increased at the beginning of the rains season, this is probably due to a high evaporation rate [18] linked to high temperatures in the water surface.

Within the Caleta system, salinity variations as consequence to the volumes of water that flows into the system and the amount of evaporated water. During the rains season, salinity decreased significantly as a consequence of pluvial runoffs and wastewater discharges; on the contrary, during the dry season there were only two contributors: wastewater and the adjacent sea. This suggests that the exchange of salt and water within the system depends on the contributors; hence the need to carry out annual studies to describe the system correctly by considering the changes caused by hurricanes and north wind season.

It is a fact that the system presents a higher input of wastewater per year $\left(613,260.00 \mathrm{~m}^{3}\right)$ compared to the precipitation volume during the dry season and the rains+north wind season (Table 2). This implies that, high contributions of different pollutants could be altering the ecosystem and affecting to the species; a potential risk to the public health is also present.

Accumulation and re-suspension of organic components contribute to decrease the oxygen rates, as observed during the rains and north wind season. The Términos lagoon and adjacent lagoons have reported similar results [19-21] suggested that when the organic material increases after the rains season, the microorganisms decompose such organic material removing the oxygen from the column of water. Particularly, in the area of exchange between Términos lagoon and the sea, the oxygen concentration increases during March and May (dry season), and reach its highest values during June and July (rains season). A high content of oxygen in the water column is related to high concentrations of chlorophyll $\boldsymbol{a}$; however, in the present study this phenomenon was only observed during the rains season (Figure 4). That could be caused by high amounts of nutrients being removed by phytoplankton which concentration increases during June and July. Some studies suggest that phytoplankton and phyto-benthos removed not only the nutrients imported from the sea but also the nutrients that come from the sediment. The influence of sediment over the nutrients regeneration enriching the water column it is not despicable, specially regarding ammonium, phosphate and silicate [22]; such phenomena occurs mainly in the Caleta lagoon during the dry season where high concentrations of DIN are present. Given the shallow depth of the system, nitrogen can move from the sediment to the water column. It has been proved that nitrogen net mineralization rates can be relatively low during most of the year, increasing from June to August probably because of temperature and microbial activity in the sediment [23]. Some studies suggest that the sediments are decisive since ammonium is the main source of exchangeable nitrogen at the sediment-water interface [24]. That could explain the nitrogen enrichment in the water column during the dry season as well as its immediate consumption during the rains and north wind season, favoring the increase of chlorophyll $\boldsymbol{a}$ at Caleta inlet station.

Such seasonal changes regarding the nitrogen concentration rates are partially associated to the nutrients from wastewater and other external inputs. During the dry season, high concentrations of DIN show that the system is mainly controlled by biological processes instead of external-physical inputs that liberate nitrogen into the water column as a subproduct of degradation (heterotrophic system). While, during the rains and north wind season, the negative fluxes of DIN 
indicate that the Caleta lagoon system works as a sink and presents the main characteristics of an autotrophic system; this suggests that after storms the rates of chlorophyll $\boldsymbol{a}$ increase. During June, July and August when the biggest storms take place, the month of July reported the highest rates of chlorophyll (10-25 $\left.\mathrm{mg} \mathrm{m}^{-3}\right)$. Hagy et al. [5] reported similar observations at Pensacola Bay where a phytoplankton bloom with chlorophyll $\boldsymbol{a}$ concentrations of $20 \mu \mathrm{g} \mathrm{l}^{-1}$ took place a month after hurricane Ivan suggesting that the dead biomass at the bottom of the water column initiates decomposition processes generating nitrogen and increasing $\mathrm{NH}_{4}^{+}$, DIP and $\mathrm{NO}_{3}{ }^{-}+\mathrm{NO}_{2}$ - fluxes as well as increasing the nitrification rate potential [6].

During the summer, the Caleta lagoon presents heterotrophic characteristics and nitrification processes dominate; similar results were reported by Valenzuela et al. [10] at the Lobos Lagoon in Mexico. Such heterotrophic conditions are associated to organic loads from mangroves and its biological degradation. Studies suggest organic loads from mangroves can modify the nitrogen and phosphorus fluxes in estuaries and can be net sources of nutrients. On the other hand, studies have reported that the mangrove detritus are equivalent to 345 $\mathrm{g} \mathrm{C} \mathrm{m}^{-2}$ year ${ }^{-1}[25,26]$. The amount of nutrients exported by mangroves can be higher to the amount exported by rivers during the dry season (31.39 ton) and the rains season (55.14 ton), hence, the amounts of nutrients exported by mangroves are higher than the amounts received [3-27].

Heterotrophic conditions have been reported in systems as Bahía de san Quintín, Baja California, México; studies by Hernández-Ayón et al. [15] suggest that during the summer external inputs of organic matter present in such quantities that respiration exceeded photosynthesis. Under such conditions, it is evident that the Caleta lagoon system receives high inputs of organic matter from local mangroves as well as from urban wastewater; after its degradation, organic matter releases nitrogen in the water column and turns the system into a nitrogen exporter.

The DIP fluxes show that, during the dry season the Caleta lagoon system export phosphorus to the adjacent sea, while during the rains+north wind season the system works as sink. The rates of imported phosphorous were lower that the rates of exported phosphorus, hence it is quite probable that most of it comes from urban wastewater discharges as well as from biological processes. The phosphorus mineralization rates within the lagoon system can vary according to the water temperature, oxygen and $\mathrm{NO}_{3}^{-}+\mathrm{NO}_{2}^{-}$concentration as well as the contents of iron which is an important element for the phosphorus release [28]. Some studies demonstrate that positive fluxes of DIP, like the ones observed as Escambia Bay, are linked to phosphorus release from the sediment to the water column; those areas with anoxic conditions presented the highest concentrations $\left(\mathrm{DO}=0.9 \mathrm{mg} \mathrm{l}^{-1}\right)$ [6].

Moreover, the increase in the microbial metabolism contributes to create anoxic conditions caused by the consumption of nutrients and organic matter, during this process iron and phosphorus are reduced and released [29]. The increasing phosphorus levels in the water column, suggest that when temperatures are high (summer) the sediment in the Caleta lagoon system releases such nutrient which enriches the system and presents positive fluxes $\left(0.0049 \mu \mathrm{mol} \mathrm{m}^{-2} \mathrm{~d}^{-1}\right)$; such phenomenon confirms the phosphorous exportation during the dry season.

Phosphorus bioavailability depends on the capacity of the sediments and suspended particles to release or sequestrate phosphates, which under such conditions keeps its concentration under a narrow interval of values [30] which limits the availability of this nutrient to phytoplankton. The short-term effects in suspended sediments lead to a highly effective performance due to phosphates dissolved among phytoplankton and sediment particles [24].

Phosphorus dynamics is related to adsorption and desorption processes. Orthophosphate ions interact with the surface of suspended particles in such way that when DIP concentrations rise particles adsorb phosphorus; when such concentrations decrease phosphorus desorbs to compensate the nutrient in the water column [31]. Aquatic sediments can be phosphorus-rich if they present an important fraction of muds and clay because these particles are so small that they represent a greater surface, besides $\mathrm{Fe}$ and $\mathrm{Al}$ oxides that cover them can adsorb important quantities of phosphorus [32,33]. Some experiments based on adsorption-desorption in sediment by Ortiz-Hernandez et al. [34] at Bahía San Quintín, Baja California, México, suggest that adsorption is the dominant effect of suspended particles on DIP, specially when there are high concentrations of small particles, hence adsorption in a particles concentration of $0.1 \mathrm{~g} \mathrm{l}^{-1}$ is higher in sandy mud sediment $\left(0.93 \mathrm{l} \mathrm{g}^{-1}\right)$, unlike fine grains of sand $\left(0.62 \mathrm{l} \mathrm{g}^{-1}\right)$; such differences are based on the number of active sites as a result of different grain sizes.

Previous granulometric studies show that Caleta lagoon system presents a higher concentration of sand $(73.5-94 \%)$, while fractions of muds are from 0.5 to $22.5 \%$; and clay from 4.0 to $9.5 \%$; suggesting that the system can present sandy muds sediment in greater proportions. On the other hand, in this kind of sediments it is more common to find higher concentrations of Fe (110.01 ppm). This is due to the fact that sediment favors the adsorption processes, thus during the rains season the phosphorus contents decrease because particles increase in the water column, while during the dry season desorption processes take place because the water column presents low mixing levels. The decrease in the phosphorus rates during the rains season forces the system to import this nutrient from the adjacent sea and can be demonstrated based on the following values: NEM (positive) 0.081 and $\Delta \mathrm{DIP}$ (negative) 0.00077 .

The impact of the wastewater discharges into the system based on BOD estimation and elimination it is an evidence that throughout the $7 \mathrm{~km}$ of the Caleta system, there is a reduction from $96 \%$ (dry season) to $78 \%$ (rains + north wind season), while BOD levels at the Caleta inlet can drop to reach $0.0035 \mathrm{mg} \mathrm{l}^{-1}$ (dry season) and $0.17 \mathrm{mg} \mathrm{l}^{-1}$ (rains + north wind season). Data obtained from water samples indicate that the BOD content was $\left(0.2-1.2 \mathrm{mg} \mathrm{l}^{-1}\right)$; low BOD levels at the Caleta inlet are the reason for the great capacity of the system to decompose organic matter. Although in this analysis organic contribution from mangroves was not considered which would increase the organic input in the system, it is possible to conclude that the system presents high self-depuration levels that favor flux dynamics of nitrogen.

\section{Conclusions}

Caleta lagoon system shows seasonal changes. The dry season is characterized by a heterotrophic system that exports nitrogen and phosphorus, while the rains season is characterized by a heterotrophic system that imports nutrients from the adjacent sea. During the summer, high concentrations of DIN indicate that the system is mainly controlled by biological processes instead of external physical inputs; hence nitrogen is released into the water column as a sub product resulting from the degradation of organic matter present in wastewater and mangrove detritus.

During the summer, the system exports phosphorus to the adjacent sea, whereas during the rains and north wind season such nutrient is 
Citation: Marín AR, López YC, Loría JCZ, Reyes R, Sarracino G, et al. (2014) Variation on the Fluxes of Nutrients in an Urban Lagoon by Seasonal Effects and Human Activities. Hydrol Current Res 5: 170. doi:10.4172/2157-7587.1000170

Page 8 of 8

imported. Given that the phosphorus import is low compared to the export during the dry season, it is possible that adsorption-desorption processes are associated to the dynamics of such nutrient in Caleta lagoon system; in other words, during the rains season the amount of particles increase in the water column and $\mathrm{P}$ can be adsorbed and decrease its content; in contrast, during the dry season desorption processes could be present.

BOD levels in wastewater are reduced when they come into the Caleta lagoon system, which indicates that it presents good levels of self-depuration with residence time equivalent to 21 day during the dry season and 16 day during the rain and north wind season.

\section{References}

1. De la Lanza-Espino G, Lozano-Montes H (1999) Comparación fisicoquímica de las lagunas de Alvarado y Términos. Hidrobiológica 9: 15-30.

2. De la Lanza-Espino G, Rodríguez-Medina MA (1990) Caracterización de la Laguna de Caimanero, Sinaloa, México, a través de algunas variables geoquímicas. Ciencias Marinas 16: 27- 44

3. Tovilla-Hernández C and De la Lanza- Espino G (2001) Balance hidrológico y de nutrientes en un humedal costero del Pacifico Sur de México. Hidrobiológica 11: $133-140$.

4. Paerl HW, Bales JD, Ausley LW, Buzzelli CP, Crowder LB, et al. (2001) Ecosystem impacts of three sequential hurricanes (Dennis, Floyd, and Irene) on the United State largest lagoonal estuary, Palmico Sound, NC. Proceeding of the National Academy of Sciences 98: 5655-5660.

5. Hagy III JD, Lehrter JC, Murrell MC (2006) Effects of hurricane Ivan on water quality in Pensacola Bay, FL, USA. Estuaries and Coasts 29: 919-925.

6. Smith KA, Caffrey JM (2009) The effects of human activities and extreme meteorological events on sediment nitrogen dynamics in an urban estuary, Escambia Bay, Florida, USA 627: 67-85.

7. Caffrey JM (2003) Production and net ecosystem metabolism in U.S. estuaries. Environmental Monitoring and Assessment 81: 207-219.

8. Caffrey JM (2004) Factors controlling net ecosystem metabolism in U.S. estuaries. Estuaries 27: 90-101.

9. Arreola-Lizarraga JA, Padilla-Arredondo G, Ortega-Rubio A (2004) Experiencias de manejo en la zona costera del Pacifico: la bahia de Guaymas, un caso específico. In: E. Rivera- Arriaga., G.J. Villalobos., I. Azuz Adeath., F. Rosado May (Ed). El manejo costero en México. Universidad Autónoma de Campeche, SEMARNAT, CETYS-Universidad, Universidad de Quintana Roo 375-386

10. Valenzuela-Siu M, Lizarraga JAA, Carrillo SS, Arredondo GP (2007) Nutrient fluxes and net metabolism in Lobos coastal lagoon, México. Hidrobiológical 17: 193-202

11. Vitousek PM, Aber JD, Howarth RW, Likens GE, Matson PA, et al. (1997) Human Alteration of the global nitrogen cycle: Sources and consequences. Ecological Applications 7: 737-750.

12. Keppler CJ, Hoguet J, Smith K, Ringgwood AH, Lewitus AJ (2005) Subletha effects of the toxic alga Heterosigma akashiwo on the southeastern oyster (Crassostrea virginica). Harmful Algae 4: 275-285.

13. Yañez-Arancibia A, Day JW (1988) Ecological characterization of the Términos Lagoon. Universidad Nacional Autónoma de México. Organización de Estados Americanos. México.

14. AWWA-APHA-WPCF, "Standard Methods for the Examination of Water and Wastewater. 19th Edn", 1105, 1995.

15. Hernández-Ayon MJ, Galindo-Bect MS, Camacho-Ibar V, García-Esquivel Z, González-Gómez MA, et al. (2004) Nutrient dynamics in the west arm of the
San Quintín Bay, Baja California, México, during and after El Niño 1997/1998. Ciencias Marinas 30: 119-132.

16. Smith SV, Hollibaugh JT (1997) Annual cycle and interannual variability of ecosystem metabolism in a temperate climate embayment. Ecol. Monogr 67: 509-533.

17. Metcalf, Eddy INC (1991) Ingeniería de Aguas Residuales. Tratamiento, vertido y reutilización, 3rd edn, España: McGraw-Hill 673-694.

18. Contreras EF (1985) Lagunas Costeras Mexicanas; Centro de Ecodesarrollo, Secretaria de Pesca, México DF, 253.

19. Rivera-Monroy VH, Christopher JM, Day JW, Twilley RR, Vera-Herrera F, et al. (1988) Seasonal coupling of a tropical mangrove forest and an estuarine water column: enhancement of aquatic primary productivity. Hidrobiologia 379 41-53.

20. Ruiz-Marín A, Campos-García S, Zavala-Loría J, Canedo-López Y (2009) Hydrological aspects of the lagoons of Atasta and Pom, México. Tropical and Subtropical Agroecosystems 10: 63-74.

21. Kennish MJ (1986) Ecology of estuaries. Physical and chemical aspect. CRC Press, Boca Raton, FL, USA, 254.

22. Forja JM, Blasco J, Gómez P (1994) Spatial and seasonal variation of in situ benthic fluxes in the Bay of Cadiz. (South-west Spain). Estuar Coast Shelf Sci 39: $127-141$

23. Cartaxana P, Caçador I, Vale C, Falcão M, Catarino F (1999) Seasona variation of inorganic nitrogen and net mineralization in a salt marsh ecosystem. Mangroves and Salt Marshes 3: 127-134.

24. Nixon SW, Granger SL, Taylor DI, Johnson PW, Buckley BA (1994) Subtida volume fluxes, nutrient inputs and the Brown tide-an alternate hypothesis. Estuar Coast Shelf Sci 39: 303-312.

25. Twilley RR (1988) Coupling of mangroves to the productivity of estuarine and coastal water. In BO Janson (ed.), Coastal-Offshore Ecosystem Interactions. Springer Verlag, Berlin, Germany: 155-180.

26. Dittmar T, Lara RJ (2001) Do mangroves rather than Rivers provide nutrients to coastal environments Routh of the Amazon Rivers? Evidence from long-term flux measurements. Marine Ecology Progress Series 213: 67-77.

27. Rivera-Monroy VH, Day JW, Twilley RR, Vera-Herrera F, Coronado-Molina C (1995) Department of Oceanography and Coastal Science and Coastal Ecology Institute, Louisiana State University, Baton Rouge, L.A. 70803, USA.

28. Smolders AJP, Lamers LPM, Moonen M, Zwaga K, Roelofs JGM (2001) Controlling phosphate release from phosphate-enriched sediments by adding various iron compounds. Biogeochemistry 54: 219-228.

29. Jensen HS, Andersen FØ (1992) Importance of temperature, nitrate, and pH for phosphate release from anaerobic sediments of 4 shallow, eutrophic lakes. Limnology and Oceanography 37: 577-589.

30. Vidal M (1994) Phosphate dynamics tied to sediment disturbances in Alfacs Bay (NW Mediterranean). Mar Ecol Prog Ser 110: 211-221.

31. Froelich PN (1988) Kinetic control of dissolved phosphate in natural rivers: A primer on the phosphate buffer mechanism. Limnol. Oceanogr 33: 649-668.

32. McManus J, Berelson WM, Coale KH, Johnson KS, Kilgore TE (1997) Phosphorus regeneration in continental margin sediments. Geochim. Cosmochim. Acta 61: 2891-2907.

33. Matthiesen $\mathrm{H}$, Leipe $\mathrm{T}$, Calado-Laima MJ (2001) A new experimental setup fo studying the formation of phosphate binding iron oxides in marine sediments. Preliminary results. Biogeochemistry 52: 79-92.

34. Ortiz-Hernández MC, Camacho-Ibar VF, Carriquiry JD, Ibarra-Obando SE, Daesslé LW (2004) Contribution of sedimentary resuspension to nonconservative fluxes of dissolved inorganic phosphorus in San Quintín Bay, Baja California: An Experimental estimate. Ciencias Marinas 30: 75-88. 